Marek Karczewski

UWM, Olsztyn

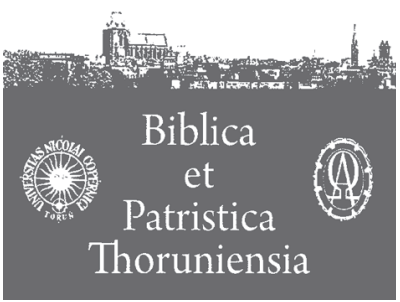

4 (2011) ISSN 1689-5150

\title{
Baranek - Lew z pokolenia Judy Chrystocentryczna reinterpretacja Rdz 49,9 \\ w Ap 5,5
}

\section{Lamb - Lion of tribe of Judah A christocentric reinterpretation of Gen 49,9 in $\operatorname{Rev} \mathbf{5 , 5}$}

Słowa kluczowe: Baranek jako Lew, Stary Testament w Nowym Testamencie, reinterpretacja, $\operatorname{Rdz} 49,9$ i Ap 5,5, chrystologia Ap.

Key words: Lamb as Lion, Old Testament in New Testament, reinterpretation, Gen 49,9 and Rev 5,5, Christology of Rev.

\section{Wstęp}

Tięga Rodzaju, choć w potocznym rozumieniu odnosi się do teologicznego rozumienia początków świata i człowieka, kryje w sobie wiele innych treści o ponadczasowym znaczeniu. Jedną z nich jest mesjańska zapowiedź o wywyższeniu Judy z Rdz 49,8-10. Użyte tam rozbudowane porównanie patriarchy z lwem zostało podjęte przez autora Ap w relacji do Jezusa Chrystusa. „Lew z pokolenia Judy” to w powszechnej opinii egzegetów jednoznaczna aluzja do tekstu Rdz 49,9. W niniejszym artykule omówiono krótko kwestię reinterpretacji tekstu Rdz 49,9 w Ap 5,5. W celu poszerzenia spectrum problemu jako wprowadzenie zaprezentowano problem złożonej sytuacji metodologicznej w przestrzeniu reinterpretacji Rdz w Ap. Sytuacja ta dotyczy także podjętej $\mathrm{w}$ artykule analizy problemu reinterpretacji obietnic danych patriarsze Judzie w kontekście tytułu Baranka. Chrystologiczne znaczenie określenia „Lew z pokolenia Judy" pozostaje w ścisłym związku z oryginalną teologią Ap. Następnie w ramach bezpośredniego omówienia związku dwóch tekstów biblijnych poruszono kwestie znaczenia Rdz 49,9 w pierwotnym kontekście literac- 
kim Księgi Rodzaju, znaczenia tytułu chrystologicznego w kontekście Ap 5,5 oraz na tle całości teologii Ap.

\section{Reinterpretacja Rdz 49,9 w Ap 5,5 - próba uściśleń metodologicznych}

W interpretacji Ap podstawowy problem stanowi złożony charakter literacki księgi związany z jej skomplikowanym językiem symbolicznym. Należy przyjąć, że w Ap nie istnieją bezpośrednie cytaty z Rdz. Istnieją natomiast motywy literackie o znaczeniu symbolicznym i wyrażenia słowne, które nawiązują do Rdz. Możne je określić jako aluzje lub odniesienia do Rdz. Ponieważ w wielu wypadkach aluzje do Rdz są włączone w kompleks jednoczesnych odniesień do innych ksiąg biblijnych konieczne jest podjęcie próby ustalenia ich wagi dla oryginalnego przesłania teologicznego Ap. Jednym z przykładów takiej kumulacji odniesień jest Ap 5,5: „Lew z pokolenia Judy” (por. Rdz 49,9) oraz „korzeń Dawida" (por. Iz 11,1.10). W przypadku omawianego przez nas wersetu sytuacja jest jednak o tyle jasna, że tytuł zaczerpnięty z Protoizajasza następuje potem, uzupełnia i precyzuje niejako tytuł nawiązujący od Księgi Rodzaju ${ }^{1}$ $\mathrm{Na}$ tle pozostałych odniesień Ap do Rdz aluzja zawarta w tytule ò $\lambda^{\prime} \epsilon \nu \nu$ ó '́火

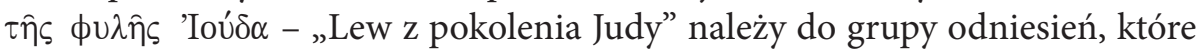
możemy określić jako pierwszorzędne aluzje do tekstu Księgi Rodzaju tej rangi co np. symbol drzewa życia ${ }^{2}$. Jest to sytuacja rzadka, zważywszy, że pierwszorzędnym środowiskiem, do którego nawiązuje autor Ap są starotestamento-

1 W przypadku niektórych złożonych figur symbolicznych odniesień może być wiele (zob. symbol niewiasty w Ap 12,1-2). Ich ciężar próbuje się zdefiniować, stosując potrójną klasyfikację jako aluzje pierwszorzędne; drugorzędne i echo. W przypadku Ap 5,5 obydwa odniesienia zdają się posiadać podobny ciężar aluzji pierwszorzędnych, zob. M. Karczewski, Reinterpretacja Ksieggi Rodzaju w Apokalipsie św. Jana, Biblioteka Wydziału Teologii Uniwersytetu Warmińsko-Mazurskiego 55, Olsztyn 2010, s. 71-76. Dyskusja nad zasadami metodologicznymi reinterpretacji Starego Testamentu w Ap nie została jednak jeszcze zakończona.

2 Zob. M. Karczewski, Reinterpretacja Księgi Rodzaju, s. 14-21. Związek między Ap i Rdz dostrzec w 28 tekstach. Tworzą one cztery podstawowe grupy tematyczne: 1) aluzje do Edenu („drzewo życia” - Ap 2,7; 22,2.14.19; „wąż starodawny” - 12,9; 20,2; „potomstwo Niewiasty” - 12,17b; „rzeka wody życia” - 22,1;2) aluzje do historii Abrahama (motyw licznego potomstwa - 1,7; 7,9; wielka rzeka Eufrat - 9,14; 16,12; Sodoma i Gomora - 9,2.17$18 ; 11,8 ; 14,10-11 ; 19,20 ; 20,10.14 ; 21,8) ; 3$ ) aluzje do cyklu Jakuba („Lew z pokolenia Judy” - 5,5; 12 synów Jakuba, protoplastów pokoleń Izraela - 7,5-8; 12,1; Józef, syn Jakuba - 12,1; 4) aluzje do szeroko pojętej mocy stwórczej Boga (Bóg Stwórca - 4,11; 10,6; 14,7; tęcza - 4,3; $10,1)$. 
we pisma prorockie. To właśnie ta zależność najbardziej interesuje egzegetów $\mathrm{i}$ jest często omawiana w środowisku naukowym ${ }^{3}$. Jak wskazuje stan debaty egzegetycznej kwestia reinterpretacji tekstów starotestamentowych w Ap może być podjęta na różne sposoby ${ }^{4}$. Relacją najbardziej typową jest zachodzący miedzy tymi tekstami związek teologiczny ${ }^{5}$. Wydaje się, że właśnie re-lektura teologiczna najbardziej interesowała autora Ap. W studiach nad tekstem Ap wysuwa się nierzadko kwestie właściwego zdefiniowania Sitz im Leben księgi oraz jej możliwych związków z literaturą pozabiblijną. Teologiczny wymiar Ap staje się przedmiotem pogłębionych studiów biblijnych relatywnie rzad$\mathrm{ko}^{6}$. Niekiedy dochodzi wręcz do marginalizacji przesłania teologicznego Ap

3 Zob. np. A. Vanhoye, L'utilisation du livre d'Ézechiel dans l'Apocalypse, Bib 43 (1962), s. 436-476; A. Lancelotti, L'utilizzazione del Deutero-Isaia nell'Apocalisse di Giovanni, „Euntes Docete" 27 (1974), s. 109-144.311-339; tenże, L'utilizzazione del TM nelle citazioni isaiane dell'Apocalisse, RivB 24 (1976), s. 113-136; G. K. Beale, The Use of Daniel in Jewish Apocalyptic Literature and in Revelation of St. John, Lanham 1984; K.A. Strand, An Overlooked Old-Testament Background to Revelation 11,1, AUSS 22 (1984), s. 317-325; J. M. Vogelsang, The Interpretation of Ezekiel in the Book of Revelation, Harvard 1985; J.-P. Ruiz, Ezekiel in the Apocalypse: The Transformation of Prophetic Language in Revelation 16,17-19,10, Frankfurt 1989; J. Fekkes, His Bride Has Prepared Herself. Revelation 19-21 and Isaian Nuptial, JBL 109 (1990), s. 269-287; tenże, Isaiah and Prophetic Traditions in the Book of Revelation: Visionary Antecedents and Their Development, JSNTSupp 93, Sheffield 1994; M Jauhisinen, The Use of Zechariah in Revelation, Tübingen 2003; B. Kowalski, Die Rezeption des Propheten Ezechiel in der Offenbarung des Johannes, SBB 52, Stuttgart 2004; W. Linke, Księga Ezechiela w Apokalipsie św. Jana, CT 77, 4 (2007), s. 79-101; itd.

4 Od próby uchwycenia typowych zależności lingwistycznych po badania nad zależnościami typu strukturalnego czy symbolicznego. Na temat różnorodnych zależności między Ap i Starym Testamentem, zob. M. Karczewski, Reinterpretacja Księgi Rodzaju, s. 2986. Wydarzeniem edytorskim w przestrzeni badań nad zależnością Nowego Testamentu od Starego dotyczącym także tekstu Ap było ukazanie się kompletnego komentarza - Commentary on the New Testament Use of the Old Testament, red. G. K. Beale, D. A. Carson, Grand Rapids - Nottingham 2007.

5 Na konieczność zwrócenia szczególnej uwagi na teologię tesktu biblijnego wskazują m.in. wypowiedzi Papieskiej Komisji Biblijnej: „De Sacra Scriptura et christologia” (1984), „Jedność i różnorodność w Kościele”, „Interpretacja Biblii w Kościele” (1993), „Naród żydowski i jego Pisma Święte w Biblii chrześcijańskiej” (2001), „Biblia i moralność. Biblijne korzenie postępowania moralnego (2008). W sposób bardzo wyraźny konieczność dowartościowania studiów teologicznych nad tekstami podkreśla Benedykt XVI, Adhortacja posynodalna Verbum Domini. O Słowie Bożym w życiu misji Kościoła, Kraków 2010, s. 41. (nr 35).

6 Istnieje ciągła nieufność wobec profetycznego i apokaliptycznego wymiaru teologii Ap. W wielu środowiskach naukowych traktuje się Ap tylko i wyłącznie jako jeden z wielu przykładów starożytnej literatury apokaliptycznej będącej efektem specyficznej sytuacji chrześcijan na przełomie I i II w. po Chr. Jednakże jak wskazują najnowsze studia nad Ap 
lub ograniczenia jej jedynie do postulatów typu etycznego. Kluczem do interpretacji teologii Ap są nie tyle jej związki ze apokaliptycznym środowiskiem judaistycznym czy z szerzej pojętym kontekstem religijno-społecznym, ale jej charakter nowotestamentowy. Istotną rolę w reinterpretacji teologicznej Ap odgrywa nie tyle poszukiwanie znanych $\mathrm{z}$ innych pism nowotestamentowych schematów teologicznych, co uchwycenie oryginalnych dla Ap treści teologicznych ${ }^{7}$. Precyzując, należy związać badania teologiczne nad teologią Ap, także w jej aspekcie reinterpretacji z osobą Jezusa Chrystusa - centralną postacią chrześcijaństwa. Głównym nurtem w zanurzonej w Starym Testamencie teologii Apokalipsy jest chrystologia teocentryczna ${ }^{8}$. Chrystologia teocentryczna Apokalipsy opiera się na aktualizacji tekstów Starego Testamentu. Kluczem do rozumienia Starego Testamentu w Ap jest wydarzenie Jezusa Chrystusa ${ }^{9}$. Odniesienia do Starego Testamentu jednocześnie umożliwiają zrozumienie wydarzenia Jezusa Chrystusa. Chrystologia Ap zachowuje daleko posuniętą oryginalność. Nie można jej traktować jako dodatku, uzupełnienia jako dodatku do chrystologii innych pism Nowego Testamentu ${ }^{10}$. Jednym z istotnych tytu-

w jej treści tkwi ogromne bogactwo teologiczne. W aktualnej sytuacji Kościoła w Europie właściwe odczytanie proroctwa Ap oraz zachowanie jej perspektywy eschatologicznej może stać się dla wspólnoty wierzących wielką szansą. Zob. m.in. A. Vögtle, Das Buch mit sieben Siegeln, Freiburg-Basel-Wien 1981; S. Haręzga, Błogosławieństwa Apokalipsy, Katowice 1982; M. Czajkowski, Apokalipsa jako księga profetycznego orędzia, Wrocław 1987; O. Böcher, Niebiańskie Jeruzalem. Spostrzeżenie na temat eklezjologii Apoklipsy św. Jana, RBL 41 (1988), s. 330-336; A. Jankowski, De Ecclesia multiformi et una secundum Apocalipsim Joannis, w: Commision Biblique Pontificale. Unité et diversité dans l'Église, Roma 1989, s. 285-295; M. Wojciechowski, Kościót jako Izrael wedtug Apokalipsy, STV 26,1 (1988), s. 221-234; F. Sieg, Określenia chrześcijan w Apokalipsie św. Jana 4-22, „Bobolanum” 1 (1990), s. 88-101; A. Kiejza, Hermeneutyka Apokalipsy; tenże, Bóg jako Ojciec według Apokalipsy św. Jana, RT XLIX, 1 (2002), s. 129-145; W. Popielewski, „Błogosławieni, którzy sa wezwani na ucztę godów Baranka” (Ap 19,9). Kościół w Księdze Apokalipsy, „Verbum Vitae” 6 (2004), s. 169-181; D. Kotecki, Duch Święty w zgromadzeniu liturgicznym w świetle Apokalipsy św. Jana, Rozprawy i Studia Biblijne 26, Warszawa 2006; tenże, Kościół w świetle Apokalipsy św. Jana, Studia Biblica Paulina 26, Częstochowa 2008.

7 Zob. R. Bauckham, La teologia dell'Apocalisse, Lettura bibliche 12, Brescia 1994, s. 39 .

8 D. Kotecki, Reinterpretatión del Antiguo Testamento en el Nuevo: Cristología teocéntrica an el Apocalipsis de San Juan”, „Scripta Theologica 40”, 2 (2008), s. 509-524. Pojęcie chrystologii teocentycznej jest nowe i jest wydaje się udaną propozycją uchwycenia specyfiki teologicznej Ap.

9 D. Kotecki, Reinterpretatión del Antiguo Testamento, s. 509.

10 Tamże, s. 511. Kwestia określenia specyficznej relacji teologicznej do poszczególnych nowotestamentowych nurtów teologicznych postaje jeszcze w dużej mierze zadaniem na przyszłość. 
łów chrystologicznych Ap jest omawiane określenie - „Lew z pokolenia Judy”. Jego wyjątkowe znaczenie w kontekście teologicznym Ap 4-5 sprawia, że jest on jednym z klasycznych przykładów świadczących o oryginalności chrystologii Ap. Oryginalność ta staje się jeszcze bardziej ewidentna w kontekście jego starotestamentowych korzeni. Bez odniesienia do Rdz 49,9 mówienie o Lwie, który jest jednocześnie Korzeniem Dawida i Barankiem Stojącym jakby Zabitym staje się niemożliwe.

\section{Reinterpretacja Rdz 49,9 w Ap 5,511}

\subsection{Rdz 49,9 w kontekście Księgi Rodzaju}

Zawarte w Ap 5,5 symboliczne imię Baranka - Lew Judy nawiązuje do tekstu Rdz 49,9, w którym pojawia się Juda, określony jako młody lew. Tekst Rdz 49,9 stanowi część tzw. Testamentu Jakuba zawartego w Rdz 49,1-33'12. Kontekst szerszy stanowi historia Józefa ${ }^{13}$ zawarta $\mathrm{w}$ Rdz $37-50$. W środowisku egzegetów przeważa jednak opinia, że historia Józefa stanowi swoistą całość różną do reszty Księgi Rodzaju ${ }^{14}$. W przestrzeni badań historyczno-krytycznych dyskusja na temat kompozycji interesującego nas kontekstu nie została jeszcze zakończona ${ }^{15}$. Podkreśla się także fakt, że główną postacią obecną w Rdz 47-50

11 Informacje zawarte $\mathrm{w}$ tym punkcie zostały zamieszczone także w monografii dedykowanej kwestii reinterpretacji Księgi Rodzaju w Apokalipsie św. Jana omówionej przez autora artykułu w M. Karczewski, Reinterpretacja Księgi Rodzaju, s. 177-182.

12 V. P. Hamilton, The Book of Genesis. Chapters 18-50, New International Commentary on Old Testament, Grand Rapids 1990, s. 644.

13 Zob. G. von Rad, Die Josephsgeschichte, BSt 5, Neukirchen-Vluyn ${ }^{4}$ 1964; J. Scharbert, Ich bin Josef euer Bruder: Die Erzählung von Josef und seiene Brüdern, wie sie nicht in der Bibel steht, St. Ottilien 1988; J. W. Dietrich, Die Josefrezählung als Novelle and Geschichtschreibung. Zugleich ein Beitrag zur Pentateuchfrage, BTZ 14, Neukirchen-Vluyn 1989.

14 J. Lemański, Pięcioksiąg dzisiaj, Studia Biblica 4, Kielce 2002, s. 238.

15 Zob. H.-Ch. Schmidt, Die Hintergründe der neusten Pentateuchkritik und der literarische Befund der Josefsgeschichte Gen 37-50, ZAW 97 (1985), s. 161-179; L. Ruppert, Zur neueren Diskussion um die Josefgeschichte der Genesis, BZ NF 33 (1989), s. 92-97; R. N. Whybray, The Joseph Story and Pentateuchal Criticism, VT 18 (1968), s. 522-528; C. Westermann, Genesis 12-50, „Exegetische Forschungen” 48, Darmstadt ${ }^{2} 1987$, s. 56-68; J.-L. Ska, La storia di Giuseppe, s. 13-18. 
jest przede wszystkim patriarcha Jakub - Izrael ${ }^{16}$. Wskazuje się na dość luźną relację $\mathrm{Rdz} 49$ do reszty tekstu $\mathrm{Rdz}^{17}$.

Testament Jakuba posiada przejrzystą strukturę literacką. W Rdz 49,1-2, przygotowując się do śmierci, Jakub zbiera swoich synów wokół siebie, aby przekazać im swoją ostatnią wolę. Kontekst rozstania sprawia, że słowa Jakuba posiadają wyjątkowy walor i odnoszą się do przyszłości jego synów ${ }^{18}$. Jakub kieruje je do każdego z synów oddzielnie. Konwencja przekazu nie jest jednolita i zależy od tego, do kogo kierowane są ostatnie pouczenia ojca. Mowa Jakuba rozpoczyna się w Rdz 49,3. Najpierw Jakub zwraca się do pierworodnego Rubena (w. 3-4), następnie do Symeona i Lewiego razem (w. 5-7), Judy (w. 8-12), Zabulona (w. 13), Issachara (w. 14-15), Dana (w. 16-18), Gada (w. 19), Asera (w. 20), Neftalego (w. 21), Józefa (w. 22-26) i Beniamina (w. 27).

Juda jest zatem wymieniony jako trzeci (por. Lb 2,3-32). W przeciwieństwie do gorzkich słów skierowanych do niektórych synów Jakub (Symeon, Lewi, Dan) wygłasza pochwałę Judy i przepowiada jego wywyższenie. Wyrocznia skierowana do Judy jest druga po względem długości po po wyroczni skierowanej do Józefa. Jakub zwraca się do Judy najpierw w drugiej osobie (Rdz 49,8-9b), natomiast potem zmienia ją na trzecią, mówiąc nie tyle do Judy, co o Judzie $(49,9 c-12)$. Kombinacja ta jest normalna dla Rdz 49,1-33. W swoim testamencie Jakub zwraca się niekiedy tylko w drugiej osobie, kiedy indziej w trzeciej lub $\mathrm{w}$ jednej i drugiej formie (por. 49,3-7). V.P. Hamilton ${ }^{19}$ podkreśla, że właściwie zawartość mowy nie odpowiada faktom z życia Judy (por. Rdz 37-38).

W Rdz 49,8 Jakub daje Judzie honorowe miejsce pośród swoich braci. Powodem tego będzie jego panowanie nad nieprzyjaciółmi ${ }^{20}$. Wywyższenie Judy zapowiada przyszłe wywyższenie Dawida ${ }^{21}$. W Rdz 48,9 Juda zostaje porównany do lwa. Podobieństwo Judy do lwa zostało wyrażone za pomocą trzech

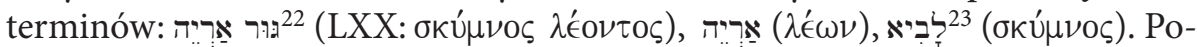
równanie Judy do lwa znajduje swoje teksty paralelne do pokoleń Gada i Dana

16 J.-L. Ska, La storia di Giuseppe, Roma 1994, s. 19.

17 Tamże.

18 G. Ravasi, Księga Rodzaju 12-50, Kraków 1997, s. 263-264.

19 V. P. Hamilton, The Book of Genesis. Chapters 18-50, s. 657.

20 Być może powodem jego wywyższenia jest protest przeciw zamordowaniu Józefa (por. Rdz 37,7).

21 V. P. Hamilton, The Book of Genesis. Chapters 18-50, s. 658.

22 Jako młode lwa, zob. L. Koehler, W. Baumgartner, J. J. Stamm, Wielki słownik hebrajsko-polski i aramejsko-polski Starego Testamentu, Warszawa 2008, t. I, s. 175.

23 Jako lwica, zob. L. Koehler, W. Baumgartner, J. J. Stamm, Wielki słownik hebrajsko-polski, t. I, s. 487. 
(Pwt 33,20.22) ${ }^{24}$ oraz w odniesieniu do Izraela w kontekście błogosławieństw Balaama (Lb 23,24; 24,9).

Juda jest jak lew sprawny i panujący nad swoimi wrogami (por. Rdz 49,8). Symbol lwa zawiera w sobie zabarwienie polityczne i religijne ${ }^{25}$. R. Krawczyk ${ }^{26}$ porównuje zróżnicowane obrazy lwa w Rdz 49,9 do etapów historii potomków Judy: młody lew zdobył doświadczenie w zwycięskich wyprawach i stał się starym, doświadczonym lwem, który odpoczywa, a nikt nie ośmiela się go niepokoić.

W bezpośrednim kontekście porównania Judy do lwa pojawia się kolejny istotny tekst, któremu tradycja judaistyczna i chrześcijańska nadaje znaczenie mesjańskie ${ }^{27}$. W Rdz 49,10 padają proroczo brzmiące słowa: „Berło nie zostanie odjęte od Jakuba, ani znaki wodza od jego nóg, aż przyjdzie ten, do którego należąa" (Ez 21,32; Mi 5,1-3; por. TestJud 24) ${ }^{28}$. Tekst wersetu uchodzi za bardzo skomplikowany pod katem użytej terminologii oraz jego interpretacji teologicznej ${ }^{29}$. Kolejne możliwe związki z Nowym Testamentem znajdują się w w. 11-12, gdzie pojawia się motyw obfitości wina oraz osła, przywiązanego do winnego krzewu (por. Zach 9,9; Mk 11,2). Obfitość wina jest tak wielka, że Juda będzie mógł wyprać w nim swoją odzież ${ }^{30}$. Na uwagę zasługuje wyrażenie

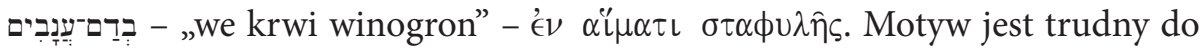
interpretacji. Sugeruje się niekiedy negatywny wydźwięk jako aluzji do sytuacji udawanego zabójstwa Józefa ${ }^{31}$. Wydaje się jednak, że obfitość wina należy łączyć z motywem mlekiem z w. 12: „zęby wybieleją mu od mleka”. W możliwej interpretacji pozytywnej wina i mleka w Rdz 49,11-12 32 jako teksty paralelne

24 W kontekście błogosławieństwa Mojżesza Gad porównany jest do lwicy a Dan do młodego lwa, zob. S. Gevirtz, Adumbrations of Dan in Jacob's Blessing on Judah, ZAW 93 (1981), s. 21-37.

25 Zob. W. Michaelis, $\lambda \lambda^{\prime} \omega \nu$, w: TWNT, t. IV, s. 256-257.

26 Nadzieje mesjańskie $w$ historii starożytnego Izraela, Warszawa 2007, s. 63.

27 Por. J. Blenkisopp, The Oracle of Judah and the Messianic Entry, JBL 80 (1961), s. 55-64 .

28 Zob. L. Boadt, Księga Rodzaju, w: Międzynarodowy Komentarz Biblijny, red. R. Farmer, Warszawa 2000, s. 308.

29 V. P. Hamilton, The Book of Genesis. Chapters 18-50, s. 658-661.

30 R. Krawczyk, Nadzieje mesjańskie, s. 66.

31 Por. C. M. Carmichael, Forbidden Mixtures, VT 32 (1982), s. 394-415.

32 V.P. Hamiltion, The Book of Genesis. Chapters 18-50, s. 656. Interpretacja negatywna jest oparta przede wszystkim na interpretacji zawartej w Targumie Neofiti Rdz 49,11-12, w które wino prezentowane jest jako krew, która rozlewa się po górach, a mleko oznacza mnóstwo wojowników, zob. M. McNamara, New Testament and the Palestinian Targum to the Pentateuch, „Analecta Biblica” 27, Rome 1966, s. 233. 
wskazuje się Iz 55,1 i Pnp 5,1. Przesłanie Rdz 49,8-12 utrzymane jest w tonacji błogosławieństwa i zapowiedzi czasów obfitości dóbr i pokoju ${ }^{33}$.

\subsection{Baranek jako Lew z pokolenia Judy w Ap 5,5}

\subsubsection{Lew z pokolenia Judy w kontekście Ap 4-5}

Werset Ap 5,5 zawierający nawiązujący do Rdz 49,9 tytuł „Baranka z pokolenia Judy" stanowi integralną część wizji niebiańskiej liturgii w Ap 4-5 $5^{34}$. Rozdziały te otwierają drugą główną część Apokalipsy określaną ogólnie jako wizje (Ap 4,1-22,5). Zasadniczo Ap 4-5 tworzą jedną rozbudowaną całość ze stałym, centralnym motywem tronu (4,4.5.6.9.10; 5,1.6.7.11.13), dwudziestoma czterema starszymi $(4,4.10 ; 5.8 .11 .14)$, czterema Istotami Żyjącymi $(4,6-8.9 ; 5,6.7 .11 .14)$ oraz tekstami poetyckimi o charakterze liturgicznym (4,8.11; 5,9-10.12.13). Elementami nowymi w Ap 5,1-14 są przede wszystkim zwój ${ }^{35}$ zapieczętowany siedmioma pieczęciami $(5,1.2 .3 .4 .6 .9$.) oraz Baranek $(5,6.8 \cdot 12.13$.$) , który jako$ jedyny jest w stanie go rozwinąć.

W kontekście literackim Ap 5,1-14 wyróżnić można następujące części wprowadzane przez ingerencję wizjonera ${ }^{36}$ : w. 1 - wizja zapieczętowanego zwoju, w. 2-5 - kwestia otwarcia zwoju, w. 6-10 - Baranek jest godzien otworzyć księgę, w. 11-12 - niebiańska aklamacja dla Baranka, w. 13-14 - uniwersalna doksologia dla Boga i Baranka.

Niezależnie od sposobu strukturyzacji Ap 5 odniesienie od „Lwa Judy” powinno być interpretowane $\mathrm{w}$ relacji do symboli zapieczętowanego zwoju oraz Baranka. W kontekście najbliższym Ap 5,5 tym, który zapowiada zwycięstwo Baranka jest Starszy. Także motyw zwycięstwa odgrywa w najbliższym kontekście decydującą rolę.

\subsubsection{Lew z pokolenia Judy jako zwycięzca}

W dyskusji egzegetycznej podkreśla się niezwykle ewidentny związek tytułu

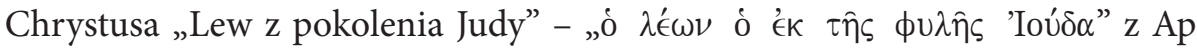
5,5 z błogosławieństwem Jakuba udzielonym Judzie z Rdz 49,9 oraz z tekstem

33 R. Krawczyk, Nadzieje mesjańskie, s. 66.

34 Zob. G. K. Beale, The Book of Revelation, Grand Rapids 1999, s. 314-315. Autor odnajduje w Ap 4-5 elementy wzorowane na strukturze Dn 7.

35 Zob. P. Prigent, L'Apocalypse de Saint Jean, Commentaire du Nouveau Testament XIV Duexiéme Sèrie, Paris 22000, s. 185.

36 D. E. Aune, Revelation 1-5, s. 327-328. 
Iz 11,1.10 (por. Rz 15,12) 37. Przytaczane w zestawieniach cytatów i aluzji teksty Iz 11,1.10 dotyczą różdżki z pnia Jessego. Rdz 49,10 zawiera obietnicę ponadto wywyższenia Judy ${ }^{38}$. G.R. Osborne wskazuje także na określenia samego Boga jako wojownika przedstawianego jako lew (Job 10,16; Iz 31,4; Jr 50,44; Oz 5,14; Am 3,8 ${ }^{39}$. Natomiast G.K. Beale i S.M. McDonough proponują dodatkowo porównanie z Jr 11,19; 23,5; 33,15; Za 3,8 ${ }^{40}$. Jr 11,19 zawiera odniesienie do baranka prowadzonego na rzeź. Jr 23,5 dotyczy powołania Mesjasza, Odrośli Dawida. Jr 33,15 zawiera zapowiedź nadejścia panowania potomka Dawida. Motyw odnowienia dynastii Dawida znajduje się także w Za 3,8.

W kontekście Ap 5,5 odniesienie do Rdz 49,9 obok Iz 11,1.11 posiada kluczowe znaczenie dla interpretacji teologicznej podstawowej dla Ap figury symbolicznej - Baranka. Wagę tytułu podkreśla fakt, że kontekście najbliższym jest to pierwszy tytuł Chrystusa, wyprzedzający nawet użycie symbolu Baranka $^{41}$. Zestawienie tytułów - „Lew z pokolenia Judy” - „potomek Dawida" podkreśla realizację zapowiedzi mesjańskich Izraela ${ }^{42}$. Baranek, który przez krzyż i zmartwychwstanie (por. Ap 5,6.9.12) dokonał zbawienia jest przede wszystkim oczekiwanym Mesjaszem, którego przyjście było wpisane w historię zbawienia od czasów patriarchów (por. Mt 1,1-17). Lew z pokolenia Judy zwyciężył. Motyw zwycięstwa posiada podwójne znaczenie. W kontekście Ap odgrywa on wyjątkową rolę i w odcieniu pozytywnym odnosi się do zwycięstwa w sensie duchowym i moralnym ${ }^{43}$. Tym, który odniósł najważ-

37 H. B. Swete, The Apocalypse od St. John, London 21907, s. 77; R.H. Charles, The Revelation of St. John, Edinburg 1920, t. I, s. 140; N-A27; U. Vanni, Apocalisse e Antico Testamento, Roma 21991, s. 51; R. Bauckham, The Climax of Prophecy. Studies on the Book of Revelation, Edinburgh 1993, s. 181 wraz z licznymi odniesieniami do literatury qumrańskiej i biblijnej; D. E. Aune, Revelation 1-5, Word Biblicak Commentary 52a, Nashville 1997, s. $350 \mathrm{z}$ odniesieniami do literatury judaistycznej i wczesnochrześcijańskiej; R. H. Mounce, The Book of Revelation. Revised, Grand Rapids 1997, s. 131; G. R. Osborne, Revelation, Baker Exegetical Commentary on the New Testament, Grand Rapids 2006, s. 253; D. J. Mac Leod, Worship in Heaven: Part 2. The Lion who is a Lamb: An Exposition of Revelation 5:1-7, BibSac 164 (2007), s. 332-333.

38 R. Bauckham, The Climax of Prophecy, s. 181.323.

39 Revelation, s. 253.

40 CNTOT, s. 1101. Podobnie U. Müller, Die Offenbarung des Johannes, Ökumenischer Taschenbuch - Kommentar zum Neuen Testament 19, Gütersloh-Würzburg 1995, s. 155; D. E. Aune, Revelation 1-5, s. 350.

41 Zob. U.B. Müller, Die Offenbarung des Johannes, s. 160-162; M. Hasitschka, Überwunden hat der Löwe aus dem Stamm Juda $(O f f b 5,5)$. Funktion und Herkunft des Bildes vom Lamm in der Offenbarung des Johannes, ZKT 116 (1994), s. 487-493.

42 Por. R. Krawczyk, Nadzieje mesjańskie, s. 67-71.

43 Zob. O. Bauernfeind, $\nu \iota \kappa \alpha ́ \omega$, w: TWNT, t. I, s. 941-945. 
niejsze, przełomowe, nieodwołalne zwycięstwo jest Jezus Chrystus. Ci, którzy zwyciężają, zwyciężają dzięki Jego zwycięstwu i Jego zwycięstwo nadaje sens ich walce ${ }^{44}$. Drugie znaczenie zawiera w sobie aluzję do obietnicy dla Judy, którą otrzymał od Jakuba. Lew z pokolenia Judy odniósł zwycięstwo zapowiedziane przez Jakuba, wpisuje się w linię zwycięstw, które odnosili potomkowie Judy, z których, Jezus Chrystus jest największym. Zwycięstwo odniesione przez mękę i zmartwychwstanie umożliwia Mesjaszowi przełamanie pieczęci, które do tej pory były nienaruszone. Otwarcie zwoju posiada wymiar symboliczny. Baranek jest Panem historii. Powagę otwarcia zwoju podkreśla celebracja niezwykłej liturgii niebiańskiej. Jej uczestnicy celebrują moment wywyższenia Mesjasza (Ap 5,9-10.12.13.14.). Słowa, które zawierają tytuł Mesjasza kierowane są do Jana przez jednego z dwudziestu czterech Starszych (Ap 4,4; 5,5-6). Ich tożsamość nie jest do końca zdefiniowana ${ }^{45}$. Niezależenie od interpretacji symbolu Starszych, są oni najprawdopodobniej związani ze wspólnotą zbawionych, zarówno z czasów starożytnego Izraela jak i członków Kościoła chrześcijańskiego. Oni uczestniczą w zwycięstwie Baranka i oddają Mu pokłon jako Bogu (Ap 5,6-8). Jan jest przedstawicielem Kościoła na ziemi (Ap 1,9). Jego płacz jest bezpodstawny, ponieważ zwyciężył Lew z pokolenia Judy. Przedstawiciel Kościoła tryumfującego wskazuje przedstawicielowi Kościoła ziemskiego Mesjasza, - Lwa, który zwycięża. Dlatego uwielbienie Baranka ogarnia nie tylko niebo, ale całe stworzenie ${ }^{46}$.

Interpretacja Rdz 49,9 dokonana w kontekście teologicznym Ap 5,5 stanowi rozwinięcie i doprecyzowanie obietnic danych Judzie i jego potomkom. Jest jednocześnie spełnieniem związanych z nimi zapowiedzi mesjańskich. Kontekst Ap dostarcza wielu informacji na temat tożsamości Potomka Judy oraz zwycięstwa, które nadaje symbolowi Lwa typowo paschalny i transcendentny

44 Zob. J. Nowińska, Motyw wojny dobra ze złem w Apokalipsie św. Jana, „Rozprawy i Studia Biblijne" 27, Warszawa 2006, s. 71-72.

45 Najbardziej logiczna interpretacja to utożsamienie 24 Starszych z układem $12+12$, tzn. przedstawiciele Izraela + przedstawiciele Kościoła chrześcijańskiego, zob. M. Hasitschka, „Presbyteros - Die Rolle der Ältesten im Volk Israel und in der frühen Kirche”, w: Ordination - mehr als eine Beauftragung?, red. K. Huber, A. Vonach, Münster-Hamburg-Berlin-Wien-London-Zürich 2010, s. 37-51.

46 D. Kotecki, Duch Święty w zgromadzeniu liturgicznym, s. 251 zauważa, że w Ap 4-5 krąg adoratorów Boga rozszerza się ogarniając całe stworzenie (Ap 5,9.12.13). 


\subsection{Lew z pokolenia Judy w perspektywie teologii $A p^{47}$}

Lew z pokolenia Judy zwyciężył i może otworzyć zwój i siedem pieczęci (Ap 5,5b). Użycie tego tytułu sugeruje, że Jezus jest Mesjaszem, który walczy, zwycięża i jest niepokonany (por. Ap 17,14; 19,11-16) ${ }^{48}$. Rys niezwykłej, zwycięskiej aktywności Baranka dotyczy wymiaru religijnego ${ }^{49}$. Samo zestawienie tytułów jest interesujące: Lew jest Barankiem. Baranek jest Lwem. Można powiedzieć, że symbol Baranka nabiera nowego znaczenia. Termin - „Baranek” (ஷ̊pvíov) w kontekście Ap odnosi się prawie zawsze do Jezusa Chrystusa ${ }^{50} \mathrm{i}$ jest podstawowym stosowanym określeniem chrystologicznym ${ }^{51}$. $\mathrm{Z}$ tego powodu chrystologia ukryta pod tym emblematycznym tytułem jest niezwykle bogata. Fundamentem treści teologicznej wyrażonej w symbolu Baranka jest oczywiście typowe także dla innych pism nowotestamentowych przekonanie, że Jezus jest prawdziwym Barankiem, ofiarą przebłagalną za grzechy ludzkości. Sama koncepcja ofiary z baranka stanowi jeden z trzonów teologii paschalnej Starego Testamentu, podjętej i rozwiniętej w Nowym Testamencie (por. J 1,29. 36; 19,33.36; 1 Kor 5,7; 1 Pt 1,18). Przekonanie o przebłagalnej śmierci Baranka - Jezusa Chrystusa jest podstawową i oryginalna prawdą chrześcijaństwa ${ }^{52}$. W kulcie świątynnym znano ofiarę poranną i wieczorną z baranka (por. Wj 29,38-42; Lb 28,3-8) choć w opinii egzegetów trudno jednoznacznie ustalić na ile praktyka ta mogła wpłynąć na autora $\mathrm{Ap}^{53}$. Z całą pewnością na chrześci-

47 Informacje zawarte w tym punkcie są w dużej mierze zbieżne $\mathrm{z}$ omówieniem zawartym w monografii dedykowanej kwestii reinterpretacji Księgi Rodzaju w Apokalipsie św. Jana omówionej przez autora artykułu w M. Karczewski, Reinterpretacja Księgi Rodzaju, s. 204-205 .

48 Zob. M. Karczewski, Jezus Chrystus jako Król królów i Pan panów (Ap 17,14b; 19,16) na tle teologii Apokalipsy, w: Ewangelia o Królestwie, red. A. Paciorek, A. Czaja, A. Tronina, Scripturae Lumen 1, Lublin 2009, s. 265-281.

49 Zob. G.K. Beale, The Book of Revelation, s. 350-351.

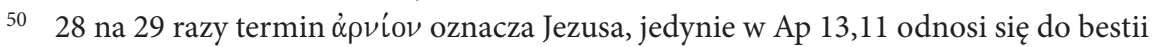
z ziemi (Fałszywy Prorok), jednak jedynie pośrednio, ponieważ bestia posiada dwa rogi podobne do rogów Baranka. Zob. M. Karczewski, Któż jest podobny do Bestii...? (Ap 13,4). Struktury władzy pomiędzy historia i proroctwem w Ap 13, ŚSHT 41,1 (2008), s. 10-20.

51 Kwestię synostwa Bożego w Biblii w perspektywie mesjańskiej omawiają A. Yarbro Collins, J. J. Collins, King and Messiah as Son of God. Divine, Human, and Angelic Messianic Figures in Biblical and Related Literature, Grand Rapids-Cambridge 2008, s. 175-203. Autorzy łączą Ap z J.

52 Zob. U. B. Müller, Die Offenbarung des Johannes, s. 162.

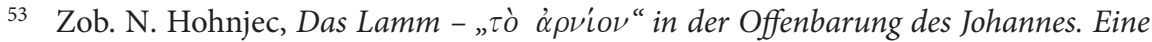
Exegetische Untersuchung, Roma 1980 s. 23-24; U. B. Müller, Die Offenbarung des Johannes, 162; R. Bauckham, The Climax, s. 184. 
jańską koncepcję Jezusa jako Baranka wpłynęła reinterpretacja trzeciej Pieśni o cierpiącym Słudze Jahwe z Iz 53,754. Choć pierwotna teologia judaistyczna nie nadawała barankowi paschalnemu znaczenia ofiary przebłagalnej ${ }^{55}$, to jednak właśnie krew baranka odgrywała w całej historii Nocy Paschalnej istotną rolę dając szansę ocalenia życia (Wj 12,21-23). Krew Baranka w Ap uwalnia od grzechu. Posiada jednak jeszcze jedną istotną właściwość. Ci, którzy płuczą w niej swoje szaty - wybielają je, czyli otrzymują udział w życiu wiecznym $(\text { Ap } 7,14)^{56}$. Ważna jest także perspektywa Wyjścia z niewoli (Ap 18,4-5). Dynamika teologii wyrażanej w symbolu Baranka rzeczywistości Wyjścia, rozpoznawalna jest $w$ treści całej Ap. Nawet wtedy, gdy Baranek jest ofiarą przebłagalną jednocześnie wskazuje na nową rzeczywistość (Ap 5,5-6; 6,1;). Baranek jest tym, który podobnie jak dobry Pasterz prowadzi w optymalnym kierunku, ku pełni życia (Ap 7,17; 14,1-5). Jest sprawcą nowego Wyjścia i nowego Izraela (por. Ap 5,10;15,3) ${ }^{57}$. To Wyjście dokonuje się ciągle (por. Ap 2-3) oraz osiągnie swoje apogeum przy końcu czasów. Baranek jest eschatologicznym małżonkiem, sprawcą ostatecznego zwycięstwa nad strukturami zła (Ap 19,7-9; 20,9). Baranek jest godny czci Boskiej, jest świątynią, oświetla swoim blaskiem niebiańską Jerozolimę i zasiada na tronie (Ap 21,22-23; 22,3).

Tytuł „Lew z pokolenia Judy”, oprócz niewątpliwego związku z teologiczną charakterystyką Mesjasza, Baranka nawiązuje do błogosławieństwa Jakuba. Może podkreślać szczególną efektywność w relacji do pogan (Ap 2,27; 12,5; 19,4; por. Ps 2,8-9). Oznacza także, że obietnice dane patriarchom izraelskim obowiązują, choć otrzymują nowy, chrystocentryczny wymiar. Wierzący w Chrystusa są zatem zaproszeni by dostrzec nowość i kontynuację w tytule, który w świetle teologii Ap nabiera wyjątkowego znaczenia.

54 Jako jeden z pierwszych na związki apokaliptycznej figury Baranka z Iz 53 wskazał J. Comblin, Le Christ dans l’Apocalypse, Paris-Tournai 1965, s. 24. Większość egzegetów dopuszcza wpływ Iz 53,7 na koncepcję Baranka w Ap. Jest to raczej wpływ na charakterystyczną dla całego Nowego Testamentu interpretację ziemskiego losu Jezusa Chrystusa, niż szczególnie na Ap, zob. U. Vanni, L’Apocalisse - ermeneutica, esegesi, teologia, „Rivista Biblica Supplementi”, Bologna 1988, s. 178.

55 H. Giesen, Die Offenbarung des Johannes, Regensburger Neues Testament, Regensburg 1986, s. 60-62.

56 Czy można wybielić szaty we krwi? Iz 1,18 mówi o wyjątkowej możliwości wybielenia krwi. Jednak Ap stosuje wyjątkową i bardzą głęboką symbolikę krwi Baranka. Jest to krew umożliwiająca udział w zmartwychwstaniu, którego Baranek „zabity i stojący” (Ap 5,6) jest pierwszym przykładem i sprawcą.

57 R. Bauckham, The Climax, s. 184. 


\section{Zakończenie}

Właściwa interpretacja tekstów Ap jest niemożliwa bez nieustannego czerpania ze bogatego skarbca teologii starotestamentowej. Niemożliwe jest podjęcie tym bardziej tematu reinterpretacji konkretnych tekstów Starego Testamentu w środowisku teologicznym Ap. Potwierdza to niezwykle piękny i działający na wyobraźnię tytuł "Lew z pokolenia Judy” - który nosi zmartwychwstały Jezus Chrystus. Obietnice raz dane przez Boga nie tracą na aktualności. Mesjasz jest potomkiem Judy. Nadaje historii jego życia i powołania do wiary nową jakość. Staje się najznamienitszym przedstawicielem jego pokolenia. W Jezusie Chrystusie chrześcijanie znajdują niezwykłą nowość, ale też kontynuację. On jest jedynym, który może otworzyć pieczęcie i stać się Panem dziejów. Dla wyznawców Chrystusa głębia teologiczna tytułu - „Lew z pokolenia Judy” powinna stawać się źródłem nadziei, szczególnie w momentach zniechęcenia i stygnięcia $\mathrm{w}$ wierze. Lew zwyciężył. Niezależnie od przeżywanych aktualnie kryzysów zwycięstwo Lwa-Baranka zachowuje swoją nieustanną, niezmienną aktualność. Jedynie On jest godzien adoracji i czci. Jego przeciwnicy są skazani na porażkę. Ci, którzy do Niego należą, mają wyjątkową szansę, by zwycięstwie wziąć udział i stać się uczestnikami obiecanej pełni życia.

\section{Summary}

The title of presentation - Lamb - Lion of tribe of Judah. A christocentric reinterpretation of Gen 49,9 in Rev 5,5 suggests the object of study - the intertextuality of biblical texts of Gen and Rev. In the methodological part we find questions of methodological problems in the theological contact between Rev - Gen. In the second part we study problem of reinterpretation Gen 49,9 in Rev 5,5. During the analysis sought to take account of the original character of the theological texts in Genesis Book, so its essential scheme is based on three points; the first- an analysis of the text of Gen 49,9. The second is to determine the context of the text in Rev 5,5 and is an attempt to theological interpretation, with particular emphasis on the intensity and contrast, or allusion to the continuation of the content of the Genesis Book. The last steep is interpretation of title "Lion of tribe of Judah" on the light of the Christology of Rev. 